\title{
An Analysis of Health Workers' Quality of Life in Indonesia During COVID-19 Pandemic
}

\author{
Ingenida Hadning ${ }^{1, *}$ N. Qurrotu' Ainii ${ }^{2}$
}

\author{
${ }^{1,2}$ School of Pharmacy, Faculty of Medicine and Health Sciences, Universitas Muhammadiyah Yogyakarta, Yogyakarta, \\ Indonesia \\ *Corresponding author.Email: ingenida.hadning@umy.ac.id
}

\begin{abstract}
Pandemic of Coronavirus Disease 2019 (COVID-19) has an impact on the life quality of health workers as the frontline in handling COVID-19 patients. This study aims to determine health workers' quality of life during the COVID-19 pandemic. This study was conducted in a observation with cross sectional technique. The population in this study was health workers in Indonesia. This study used non-probability sampling methods by 30 days of distributing e-questionnaires. The inclusion criteria of this study were men and women who work as health workers, aged 18-65 years old and were willing to become the respondents. The exclusion criteria were to not complete the questionnaire. The instrument used for this study was WHOQOLBREF. The health workers' quality of life was analyzed descriptively by calculating the average transformed score of each domain. The sample for this study was 184 respondents consisting of 114 women and 70 men. 82 respondents aged 18-25, 90 respondents aged 26-45, and 12 respondents aged 46-65. The analysis of health workers' quality of life resulted: the physical health domain got an average score of $63.18 \pm 10.62$, the psychological health domain got an average score of $60.33 \pm 15.44$, the social relation domain got an average score of $51.57 \pm 17.61$, and the environmental domain got an average score of $57.28 \pm$ 12.48. In conclusion, health workers have a good physical health, a good psychological health, a moderate social relation, and a moderate environment during the COVID-19 pandemic.
\end{abstract}

Keywords: COVID-19, health workers, quality of life, WHOQOL-BREF

\section{INTRODUCTION}

Coronavirus Disease (COVID-19) is a respiratory disease caused by 'Severe Respiratory Syndrome Coronavirus 2' (SARS-CoV-2) [1]. This virus can be transmitted from human to human aggressively through droplets released when coughing or sneezing [2]. In humans, SARS-CoV-2 infects the respiratory tract, especially the cells lining the alveoli [3]. The first reported case of COVID-19 occurred in Wuhan, Hubei Province, China. According to reports, there were five treated patients with SARS, then the disease spread to various other countries [1]. Other risk factors determined by the Centers for Disease Control and Prevention are close contact, including living in the same house with a COVID-19 patient, and travel history to and from affected areas. Being in the same environment but not in close contact (within a 2 meter radius) is considered a low risk [4]. Medical personnel or health workers are one of the populations at high risk of contracting as the front line in patient management [5]. Clinical manifestations in COVID-19 patients have a broad spectrum, ranging from asymptomatic, mild symptoms, pneumonia, severe pneumonia, ARDS, sepsis, to septic shock [5].

Quality of life is an individual's perception of their position in life related to the cultural context and value systems in which they live, which are related to goals, expectations, standards and concerns [6]. The World Health Organization Quality of Life (WHOQOL) made a
WHOQOL-BREF instrument where there are 4 dimensions of quality of life, namely physical health, psychological health, social relations, and the environment which are used as a tool to measure the quality of life which contains 26 question items [7]. The COVID-19 pandemic is considered to trigger depression and anxiety (feeling blue). This can be found in people who have lost their freedom, are separated from loved ones, and lost their jobs. This pandemic causes boredom, frustration, bad moods and potential depression. Feeling blue arises from fear of transmission and unclear sources of information spread on social media [8]. Based on this background, this research was conducted to determine the quality of life of health workers during the COVID-19 pandemic.

\section{METHOD}

This research was conducted using an observational method with a cross-sectional approach, in which the analysis with variable measurements was only carried out once at a time with no follow-up. This research was conducted from June to August 2020 with the distribution of e-questionnaires throughout Indonesia.

The population in this study were health workers in Indonesia. This research sample was taken from the results of sampling for 1 month with non-probability sampling methods. The inclusion criteria were health workers, male and 
female, aged 18-65 years and willing to become respondents. The exclusion criteria were respondents who did not complete the questionnaire completely.

The instrument used in this research was an equestionnaire distributed via social media. The questionnaire used to assess the quality of life refers to The World Health Organization Quality of Life (WHOQOL-BREF).

Analysis of research data began with testing the validity and reliability of the questionnaire. The validity test is conducted to measure the validity of a test [9]. Meanwhile, the reliability test is used to determine the consistency of measuring instruments, where the measuring instrument has the ability to be relatively consistent if the measurement is repeated [10]. The validity and reliability test in this study uses the WHOQOL-BREF validity and reliability test in the Indonesian version which has a similar population.

The quality of life analysis was carried out by measuring the score of each question item in the form of a Likert scale. The number of questions in the WHOQOL questionnaire was 26 items, which consisted of 4 health domains: physical health, psychological health, social relationship health, and environmental health. For each respondent, the raw score for each dimension was calculated. The score obtained from each dimension would be transformed on a scale of 0-100 using the standard formula set by WHO below:

\section{TRANSFORMED SCORE $=($ SKOR-4 $) *(100 / 16)$}

To interpret the mean transformed score, the results interpretation table in Table 1 can be used [11].

Table 1. Interpretation of WHOQOL-BREF transformed score

\begin{tabular}{|l|l|}
\hline $\begin{array}{l}\text { Transformed } \\
\text { Score }\end{array}$ & Interpretation \\
\hline $0-20$ & The quality of life is very poor \\
\hline $0-20$ & Poor quality of life \\
\hline $21-40$ & Quality of life is moderate \\
\hline $41-60$ & Quality of life is good \\
\hline $61-80$ & Quality of life is very good \\
\hline
\end{tabular}

\section{FINDING AND DISCUSSION}

\subsection{Validity and Reliability Test}

The WHOQOL-BREF questionnaire is a standardized questionnaire from WHO which the order of the questions cannot be changed, so to test the validity and reliability of this research, the researchers used results of validity and reliability test of a previous research WHOQOL-BREF questionnaire which had similar populations. Research by Purba, et al. (2018) [12] stated that all question items in the WHOQOL-BREF questionnaire have $r_{\text {count }}>0.361$, so that all questions are valid. The reliability test of the WHOQOLBREF questionnaire has $\alpha_{\text {count }}$ of $0.930(>0,600)$, which means the WHOQOL-BREF questionnaire is reliable or can be trusted with very strong or very reliable results' interpretations.

\subsection{Respondent Characteristics}

In this study, the distribution of questionnaire was carried out through social media platforms throughout Indonesia for 1 month (30 days) by redistributing the questionnaire twice a week. The number of respondents obtained was 184 people who had met the inclusion and exclusion criteria of this study.

The distribution of the respondents' domicile by province is shown in table 2 .

Table 2. Respondent Domicile Distribution

\begin{tabular}{|c|c|c|c|}
\hline \multirow[t]{2}{*}{ No } & \multirow[t]{2}{*}{ Province } & \multicolumn{2}{|c|}{ Quantity } \\
\hline & & $N$ & $\%$ \\
\hline 1 & Central Java & 12 & 6,52 \\
\hline 2 & $\begin{array}{l}\text { Special Region of } \\
\text { Yogyakarta }\end{array}$ & 9 & 4,89 \\
\hline 3 & South Borneo & 9 & 4,89 \\
\hline 4 & Aceh & 7 & 3,80 \\
\hline 5 & East Java & 7 & 3,80 \\
\hline 6 & Bengkulu & 6 & 3,26 \\
\hline 7 & Banten & 6 & 3,26 \\
\hline 8 & $\begin{array}{l}\text { Special Capital District of } \\
\text { Jakarta }\end{array}$ & 6 & 3,26 \\
\hline 9 & Bali & 6 & 3,26 \\
\hline 10 & Gorontalo & 6 & 3,26 \\
\hline 11 & Jambi & 5 & 2,72 \\
\hline 12 & South Sumatra & 5 & 2,72 \\
\hline 13 & Lampung & 5 & 2,72 \\
\hline 14 & Bangka Belitung Islands & 4 & 2,17 \\
\hline 15 & West Java & 5 & 2,72 \\
\hline 16 & West Nusa Tenggara & 5 & 2,72 \\
\hline 17 & East Nusa Tenggara & 5 & 2,72 \\
\hline 18 & North Kalimantan & 5 & 2,72 \\
\hline 19 & Central Kalimantan & 5 & 2,72 \\
\hline 20 & East Kalimantan & 5 & 2,72 \\
\hline 21 & West Sulawesi & 5 & 2,72 \\
\hline 22 & Central Sulawesi & 5 & 2,72 \\
\hline 23 & Southeast Sulawesi & 5 & 2,72 \\
\hline 24 & North Maluku & 5 & 2,72 \\
\hline 25 & Maluku & 5 & 2,72 \\
\hline 26 & West Papua & 5 & 2,72 \\
\hline 27 & North Sumatra & 4 & 2,17 \\
\hline 28 & West Sumatra & 4 & 2,17 \\
\hline 29 & Riau & 4 & 2,17 \\
\hline 30 & Riau Islands & 4 & 2,17 \\
\hline 31 & West Kalimantan & 4 & 2,17 \\
\hline 32 & North Sulawesi & 4 & 2,17 \\
\hline 33 & Papua & 4 & 2,17 \\
\hline 34 & South Sulawesi & 3 & 1,63 \\
\hline Tot: & & 184 & 100,00 \\
\hline
\end{tabular}

Based on the data in table 2, the majority of respondents were domiciled in Central Java with a percentage of $6.5 \%$, followed by Special Region of Yogyakarta and South Kalimantan with the same percentage of $4.9 \%$, while the smallest percentage of respondents was domiciled in South 
Sulawesi. The domicile of respondents was evenly distributed because all provinces were represented. As the next step, the grouping of respondent characteristics is based on gender, age range, domicile, and duration of social distancing while undergoing social distancing as an action to prevent the spread of COVID-19.

\subsubsection{Respondents' Gender}

The distribution of the respondents' gender is shown in table 3 .

Table 3. Gender Distribution

\begin{tabular}{|l|l|l|}
\hline \multirow{2}{*}{ Gender } & \multicolumn{2}{|l|}{ Quantity } \\
\cline { 2 - 3 } & $\boldsymbol{N}$ & $\mathbf{\%}$ \\
\hline Male & 70 & 38,04 \\
\hline Female & 114 & 61,96 \\
\hline Total & $\mathbf{1 8 4}$ & $\mathbf{1 0 0 , 0 0}$ \\
\hline
\end{tabular}

Based on the table 3, the majority of respondents are female with a percentage of $62.0 \%$. This difference in distribution could be influenced by the tendency for women to have higher social media consumption than men [13]. Moons, et al. (2004) in Nofitri (2009) [14] pointed out that gender is one of the factors that affect the quality of life. Herawati and Sasana (2013) [15] stated that gender can affect the level of work productivity.

\subsubsection{Respondents' Age} 4.

The distribution of the respondents' age is shown in table

Table 4. Distribution of Respondents' Age

\begin{tabular}{|l|l|l|}
\hline \multirow{2}{*}{ Age } & Quantity \\
\cline { 2 - 3 } & $\boldsymbol{N}$ & $\%$ \\
\hline 18-25 years old & 82 & 44,57 \\
\hline 26-45 years old & 90 & 48,91 \\
\hline 46-65 years old & 12 & 6,52 \\
\hline Total & $\mathbf{1 8 4}$ & $\mathbf{1 0 0 , 0 0}$ \\
\hline
\end{tabular}

Based on the data in table 4, the majority of respondents in this study were in the age range of 26-45 with a percentage of $48.91 \%$. Aulia Nur (2014) [13] explained that people aged 20-29 years old and 30-39 years old use electronic mass media as their main information consumption, while people over 40 years old use television as the main information consumption.

The working age allowed by Indonesia's government is at least 18 years old, and the retirement age is regulated in company regulations, cooperation agreements, or laws and regulations. These two things are stated in labour laws, Undang-Undang No. 13 Tahun 2003 tentang Ketenagakerjaan. Moons, et al. (2004) and Dalkey (2002) in Nofitri (2009) [14] state that age is a factor that can affect quality of life. Herawati and Sasana (2013) [15] state that a productive age results in higher productivity.

\subsection{Quality of Life Analysis}

COVID-19 pandemic has an impact on social and behavioural, including the quality of life [16]. The quality of life in this research was analyzed using descriptive analysis. It was as the research conducted to determine the existence of independent variables, either only in one or more variables without making comparisons and looking for relationships between these variables and other variables [17].

The total number of questions in the WHOQOL-BREF quality of life questionnaire was 26 items. Two of the questions are questions about the quality of health in general, but these two questions do not need to be scored because they cannot actually represent the general quality of life of the respondents [18]. Quality of life is described in four dimensions, namely dimensions of physical health, psychological health, social health, and environmental health.

The analysis of health workers' quality of life by gender is shown in table 5 .

Table 5. Analysis of Health Workers' Quality of Life by Gender

\begin{tabular}{|l|l|l|l|}
\hline Variables & Gender & Mean & SD \\
\hline Physical & Male & 63,014 & 10,492 \\
\cline { 2 - 4 } Health Domain & Female & 63,281 & 10,749 \\
\hline Psychological & Male & 62,400 & 11,141 \\
\cline { 2 - 4 } Health Domain & Female & 59,061 & 17,498 \\
\hline Social Relation & Male & 51,729 & 15,065 \\
\cline { 2 - 4 } Health Domain & Female & 51,474 & 19,062 \\
\hline Environmental & Male & 59,086 & 11,024 \\
\cline { 2 - 4 } Health Domain & Female & 56,167 & 13,214 \\
\hline
\end{tabular}

Based on the data in table 5, the quality of physical health of female respondents was more or less the same as that of male respondents, both of which had good score interpretation results. This is consistent with research conducted by Supriyatna, et al. (2018) [19] stating there is no significant difference between the physical activities of women and men.

The psychological health quality of male respondents had a higher average than female respondents, the interpretation results of male respondents were good while for female respondents, it was moderate. This is in accordance with the results of research conducted by Diego, et al. (2018) [20] stating women tend to have lower psychological health quality.

The average score of social relation health domain among male respondents was more or less the same as among female respondents, both of which had moderate interpretation results. This is in accordance with the theory put forward by Antonucci and Akiyama (1987) [21] stating the social relations between women and men are similar in small spheres such as family, children, relatives, and close friends.

The quality of environmental health in male respondents was higher than in female respondents, both of whom had moderate interpretation results. This is in accordance with 
Suhardin's (2016) [22] statement that men have a higher knowledge of basic ecological concepts than women.

Following the gender part, the results of the analysis of the quality of life of health workers based on their age are shown in table 6.

Table 6. Analysis of Quality of Life for Health Workers by Age

\begin{tabular}{|l|l|l|l|}
\hline Variables & Age & Mean & SD \\
\hline Physical & $18-25$ & 63,256 & 9,917 \\
\cline { 2 - 4 } Health Domain & $26-45$ & 63,411 & 11,031 \\
\cline { 2 - 4 } & $46-65$ & 60,917 & 12,760 \\
\hline Psychological & $18-25$ & 58,500 & 14,363 \\
\cline { 2 - 4 } Health Domain & $26-45$ & 61,133 & 15,979 \\
\cline { 2 - 4 } & $46-65$ & 66,833 & 17,502 \\
\hline Social Relation & $18-25$ & 46,354 & 25,976 \\
\cline { 2 - 4 } Health Domain & $26-45$ & 55,000 & 17,659 \\
\cline { 2 - 4 } & $46-65$ & 61,500 & 18,643 \\
\hline Environmental & $18-25$ & 53,024 & 10,158 \\
\cline { 2 - 4 } Health Domain & $26-45$ & 60,156 & 11,876 \\
\cline { 2 - 4 } & $46-65$ & 64,750 & 20,623 \\
\hline
\end{tabular}

In table 6 , the quality of physical health of the three age groups has a good score of interpretation, but elderly respondents have the smallest average score of all. Papalia et al. (2001) and Ariyanti (2009) in Anis, et al., (2012) [23] stated that in elderly age, a person will experience declining changes in physical, cognitive, and psychological aspects.

In terms of the quality of psychological health, the older the respondent, the greater the average score on quality of psychological health. Anis, et al., (2012) [23] explained that in elderly age, the main development that occurs is understanding and accepting the physical and psychological changes and then adapting to the situation. According to Anis, et al., (2012) [23], someone who experiences high emotional intelligence can control himself, control emotions, motivate himself, and direct himself to be more productive.

In social relation health domain, the older the respondents, the greater the average score of social relationship quality. Syamsuddin (2008) [24] states that spiritual and social activities are of the highest value for the elderly to find meaning and sense of self-worth. Social relationships that can be formed are gathering with family or friends, and feeling empathy for the same fate as the surroundings.

Table 6 shows that the older the respondent is, the greater the average score obtained, which means the quality of environmental health is getting better. Goode (1994) in Anis, et al. (2012) [23] argue that the quality of one's life reflects the cultural wealth and surroundings. The elderly need to have a safe, serene, and pleasant living environment so that the quality of their environmental health is good.

The results of the analysis of the quality of life of health workers in Indonesia during COVID-19 pandemic are shown in table 7.
Table 7. Respondents' Average Quality of Life

\begin{tabular}{|l|l|l|}
\hline Category & Average & Intepretation \\
\hline Physical Health & $63,18 \pm$ & Good \\
Domain & 10,62 & \\
\hline Psychological Health & $60,33 \pm$ & Good \\
Domain & 15,44 & \\
\hline Social Relation & $51,57 \pm$ & Moderate \\
Health Domain & 17,61 & \\
\hline Environmental Health & $57,28 \pm$ & Moderate \\
Domain & 12,48 & \\
\hline
\end{tabular}

Based on the data in table 7 , the interpretation results of the average quality score for physical health and psychological health domains are good while both domains of social relation health and environmental health got a moderate average interpretation.

\subsubsection{Physical Health Domain}

Koshuta (2015) [25] and Agustianti (2006) [26] explained the definition of physical health as a condition in which the body is fit, healthy, not attacked by any disease, and organs can function optimally to carry out daily activities independently. Total physical health domain questions in the questionnaire were 7 items, containing questions regarding pain and discomfort (item 3), medical treatment needs (item 4), daily energy needs (item 10), mobility ability (item 15), need for sleep and rest (item 16), ability to perform daily activities (item 17), and ability to work (item 18).

In table 7, analysis results of quality of life, physical health domain got an average transformed score of $63.18 \pm 10.62$. This means that the physical health quality of health workers in Indonesia during COVID-19 pandemic is categorized as good. Factors that can support the quality of physical health are physical activity (strength, flexibility and endurance), diet and nutrition (nutrient intake, fluid intake and a healthy digestive system), not consuming alcohol and drugs, selfmedicated habits (illness minor, injury, and emergency care efforts), and adequate rest and sleep (Koshuta, 2015) [25].

\subsubsection{Phychological Health Domain}

Pieper and Uden (2006) [27] defined a healthy psychology as a condition in which a person does not blame himself, is realistic and accepts his shortcomings, is able to face problems, is satisfied with social conditions, and feels that his life is happy. The total number of questions on the psychological health domain in the questionnaire was 6 items consisting of questions related to positive feelings (item 5), spirituality (item 6), thinking ability (item 7), appearance (item 11), self-esteem (item 19), and negative feelings (item 26).

In table 7, analysis results of quality of life, psychological health domain have an average transformed score of $60.33 \pm$ 15.44. This means that the psychological health quality of health workers in Indonesia during COVID-19 pandemic is categorized as good. 
Analysis by Sutikno (2015) [28] described the factors that affect the quality of mental or psychological health are gender, family function, physical health, and the environment. Family functions that run well will provide support and affection so as to improve the quality of psychological health. The relationship that occurs in the quality of physical health with the quality of psychological health is that someone who experiences certain diseases can feel depression, so that the quality of psychological health decreases.

\subsubsection{Social Relation Health Domain}

Social relations according to Wardiyatmoko (2009) in Fihayati (2014) [29] is an activity that connects individuals, individuals to groups, or between groups, which directly or indirectly creates a sense of mutual understanding and mutually beneficial cooperation. The total number of questions on the health domain of social relations in the questionnaire consisted of 3 questions consisting of social/personal relations questions (item 20), social support (item 21), and sexual satisfaction (item 22).

In table 7, analysis results of quality of life, social relation health domain have an average transformed score of $51.57 \pm$ 17.61. This means that the health quality of the social relations of health workers in Indonesia during COVID-19 pandemic is categorized as moderate.

Sekarwiri (2008) in Jacob and Sandjaya (2018) [30] stated that social relationships include personal relationships, social support, and sexual activity. Personal relationship can be in the form of relationship with oneself or with others, social support means assistance from the surrounding environment to individuals, and sexual activity describes sexual activities carried out by individuals.

\subsubsection{Environmental Health Domain}

Himpunan Ahli Kesehatan Lingkungan Indonesia (HAKLI) in Mundiatum and Daryanto (2015) [31] defines environmental health as a condition in which the environment is able to support a dynamic ecological balance between humans and their environment, in order to achieve a healthy and happy quality of human life. The total number of questions on the environmental health domain in the questionnaire was 8 items consisting of questions regarding safety (item 8), environment (item 9), finance (item 12), availability of information (item 13), opportunities to have fun (item 14), living quarters (item 23), and health facility services (item 24).

In table 7, analysis results of quality of life, the environmental health domain got an average transformed score of $57.28 \pm 12.48$. This means that the environmental health quality of health workers in Indonesia during COVID19 pandemic is categorized as moderate.

Sekarwiri (2008) in Jacob and Sandjaya (2018) [30] pointed out that dimensions of environmental health are financial resources, freedom, a sense of security both psychologically and physically, health services, social care, updating of information, recreation, satisfaction of the physical environment, and transportation.

It is important to note the limitations of our study. Even though it involves all provinces in Indonesia, the number of respondents is still limited. It is better if the number of respondents is more so that the data is more varied.

\section{CONCLUSION}

During the COVID-19 pandemic, health workers have good physical health quality, good psychological health, moderate social relationship quality, and moderate environmental health.

\section{AUTHORS' CONTRIBUTIONS}

Concept and design; analysis and interpretation of data; critical revision of the paper for important intellectual content: Hadning.

Acquisition of data; statistical analysis; drafting of the manuscript: Qurrotu' Ainii.

\section{ACKNOWLEDGMENTS}

This research is supported by Universitas Muhammadiyah Yogyakarta.

\section{REFERENCES}

[1] World Health Organization. "Coronavirus Disease Outbreak Situation".2020. https://www.who.int/emergencies/diseases/novelcoronavirus-2019 accessed on May 14, 2020.

[2] Han Y and Yang H. "The transmission and diagnosis of 2019 novel coronavirus infection disease (COVID-19)". China: J Med Virol. 2020.

[3] Zhang H, Penninger JM, Li Y, Zhong N, and Slutsky AS. "Angiotensin Converting Enzyme 2 (ACE-2) as a SARS-CoV-2 Receptor: Molecular Mechanisms and Potential Therapeutic Target”. Canada : Intensive Care Med. 2020.

[4] Centers for Disease Control and Prevention and Other. "Interim US Guidance for Risk Assessment and Public Health Management of Persons with Potential Coronavirus Disease 2019 (COVID-19) Exposures: Geographic Risk and Contacts of Laboratory-confirmed Cases". $\quad$ https://www.cdc.gov/coronavirus/2019ncov/php/riskassess-ment.html. 2020.

[5] Adityo Susilo, C. Martin Rumende, Ceva W Pitoyo, Widayat Djoko Santoso, Mira Yulianti, Herikurniawan, et al. "Coronavirus Disease 2019: Tinjauan Literatur Terkini". Jakarta : Fakultas Kedokteran Universitas Indonesia. 2020. 
[6] Wahyuni, Dwi. "Quality of Life for Outpatient Interprofessional Education (IPE) at Asri Medical Center (AMC) Yogyakarta". Yogyakarta: Muhammadiyah University of Yogyakarta. 2016.

[7] Sekarwiri, E. "Relationship between Quality of Life and Sense of Community for DKI Jakarta Residents Living in Flood Prone Areas".

[8] Venkatesh, Ashwin and Edirappuli, Shantal. "Social Distancing in COVID-19: What Are The Mental Health Implications?". Cambridge. University of Cambridge. 2020.

[9] Nofitri. "Overview of the Quality of Life of Adult Populations in Five Regions in Jakarta". http://lontar.ui.ac.id/ file?fle $=$ digital $/ 125595155.9 \% 20 \mathrm{NOF} \% 20 \mathrm{~g} \% 20$ $\%$ 20Gambaran\%20quality\%20-\%20HA. accessed on April 23, 2020.

[10] Arikunto, Suharsimi. "Research Procedure, A Practice Approach". Jakarta: PT. Rineka Cipta. 1996.

[11] Ghozali, I. "Multivariate Analysis Application with IBM SPSS 23 Program". Semarang: Diponegoro University Publishing Agency. 2016.

[12] Purba, Fredrick D, et al. "Quality of life of the Indonesian general population: Testretest reliability and population norms of the EQ-5D-5L and WHOQOLBREF." https://doi.org/10.1371/journal.pone.0197098. 2018.

[13] Aulia Nur. "The Effect of Age, Education Level, and Gender on Media Consumption Behavior”. Semarang: Diponegoro University. 2014.

[14] Nofitri. "Overview of the Quality of Life of Adult Populations in Five Regions in Jakarta". http://lontar.ui.ac.id/ file?fle $=$ digital $/ 125595155.9 \% 20 \mathrm{NOF} \% 20 \mathrm{~g} \% 20$ $\% 20$ Picture $\% 20$ quality $\%$ 20-\% 20HA. accessed on April 23, 2020.

[15] Herawati and Sasana. "Analysis of the Effect of Education, Wages, Work Experience, Gender, and Age on the Productivity of Tegal City Shutllecock Industrial Workforce”. Semarang: Diponegoro University. 2013.

[16] Jay J. Van Bavel, Robb Willer, Paulo S Boggiio, Valerio Caprapo, Mina Cikara, Alia J. Crum, et al. 2020. "Using Social and Behavioural Science to Support COVID-19 Pandemic Response". New York : Standford University. 2020.

[17] Sugiyono. "Qualitative Quantitative Research Methods, and R \& D”. Bandung: Alfabeta. 2020.

[18] World Health Organization. "WHOQOL User Manual". Geneva : World Heath Organization. 1998.
[19] Supriyatna, Fitri, and Jajat. "Differences in the Physical Activity of Boys and Girls Who Participate in the Dago Car Free Day in Bandung City". Bandung: Indonesian Education University. 2018.

[20] Diego, Ana, and Jose. "Gender Differences in Psychological Well-Being and Health Problem Among European Health Professionals: Analysis of Psychological Basic Needs and Job Satsfication". Spain: International Journal of Environmental Research and Public Health. 2018.

[21] Antonucci, Lansford, and Akiyama. "Difference between Men and Women in Social Relations, Rerource Deficits, and Depressive Symptomatology During Later Life in Four Nation". Michigan : University of Michigan. 2002.

[22] Suhardin. "The Effect Of Sex Differences And Knowledge On Basic Ecological Concepts On Environmental Concerns". Jakarta : Universitas Ibnu Chaldun. 2012.

[23] Anis, Purwaningsih, and Khoridatul."Quality of Life for the Elderly". Malang: Airlangga University. 2012.

[24] Al Adawiyah and Syamsuddin H.So that the camp is not just status. Surakarta: Indiva Media Creation. 2008.

[25] Koshuta, J. "What Is Physical Health? -Definition, Components \& Examples". https://study.com/academy/lesson/what-is-physicalhealth -definition-components-examples.html. Accessed on July 18, 2020.

[26] Agustianti, Dwi. "Relationship between Social Support and Quality of Life for People Living with HIV / AIDS (PLWHA) in Bandar Lampung City". Accessed on July 18,2020

[27] Pieper, J. and Uden, M. V. "Religion in Coping and Mental Health Care”. New York : Yord University Press. 2006.

[28] Sutikno, Ekawati. "Factors Associated with Mental Health Disorders in the Elderly: Cross Sectional Study in the Surya Group Kediri Healthy Heart Group”. Kediri: Wijayata Journal. 2015.

[29] Fihayati, Hasyim, and Adha. "Analysis of Students 'Understanding and Attitudes towards Students' Social Relations with Different Cultures". Lampung: University of Lampung. 2014.

[30] Jacob and Sandjaya. "Factors Affecting the Quality of Life of the Karubaga Community, Tolikara District, Papua Province". Papua: National Journal of Health Sciences. 2018.

[31] Mundiatum and Daryanto. "Environmental Health Management”. Yogyakarta: Gava Media. 2015. 